\title{
FDI DETERMINATION AND CORPORATE TAX COMPETITION IN A VOLATILE WORLD
}

\author{
MAURO GHINAMO \\ PAOLO M. PANTEGHINI \\ FEDERICO REVELLI
}

CESIFO WORKING PAPER NO. 1965

CATEGORY 1: PUBLIC FinANCE

APRIL 2007

An electronic version of the paper may be downloaded

- from the SSRN website:

- from the RePEc website:

www.SSRN.com

- from the CESifo website:

Www.RePEc.org

www.CESifo-group.de 


\title{
FDI DETERMINATION AND CORPORATE TAX COMPETITION IN A VOLATILE WORLD
}

\begin{abstract}
This paper investigates the role of economic and political volatility in the process of corporate tax-rate determination. The article is based on a theoretical framework that allows for the ability of multinational firms to choose the optimal timing of foreign investment and to shift profits by transfer pricing, and provides an empirical analysis on a large panel data set of countries over the 1983-2003 period. First, a reduced-form dynamic equation of corporate tax rate determination is estimated by the generalised method of moments (GMM), where a country's top statutory corporate tax rate depends on a number of measures of economic and political volatility. The fundamental testable prediction derived from the theoretical model is that increased volatility should reduce a country's corporate tax rate. Our results support the hypothesis that economic volatility is associated with lower top statutory corporate tax rates, while our measures of political volatility have no significant impact on corporate taxation policy. In order to identify the channels through which volatility works, we also estimate a structural model allowing for simultaneous determination of the corporate tax rate and the inflow of FDI to a particular country. The estimates of the structural model show that economic volatility affects the corporate tax setting process through their impact on FDI inflow.
\end{abstract}

JEL Code: C23, F23, H87.

Keywords: foreign direct investment, tax competition, volatility.

Mauro Ghinamo
Department of Economics
University of Torino
Via Po, 53
10124 Torino
Italy

Paolo M. Panteghini

Department of Economics

University of Brescia

Via San Faustino 74/B

25122 Brescia

Italy

panteghi@eco.unibs.it

\author{
Federico Revelli \\ Department of Economics \\ University of Torino \\ Via Po, 53 \\ 10124 Torino \\ Italy \\ federico.revelli@unito.it
}




\section{Introduction}

Recent empirical research has addressed the important issue of corporate income taxation in a context of globalisation and perfect capital mobility (Devereux et al. [19], [20], Bretschger and Hettich [6], Markusen [32], Rodrik [42], Slemrod [43], Winner [45], Haufler et al. [25]). The liberalization of foreign exchange laws that occurred in most OECD countries in the mid and late 1980s basically implied free mobility of capital and generated a sharp rise in FDI and multinational activity, creating the conditions for international tax competition for mobile capital. ${ }^{1}$ International pressure for tax competition has consequently been deemed responsible for the decline in the statutory corporate tax rates since the mid 1980s. ${ }^{2}$ In line with Rodrik [42], Devereux et al. [19] showed that the relaxation of capital controls stimulates tax competition and thus reduces both statutory and effective tax rates. Slemrod [43] came to a similar conclusion, where there is consistent evidence of international competitive pressure, with the degree of capital market openness being negatively associated with statutory corporate tax rates. Finally, based on panel data on samples of OECD countries, Bretschger and Hettich [6], Haufler et al. [25] and Winner [45] found that capital mobility exerts a negative impact on capital tax burden and a positive one on labour tax burden.

This paper aims to estimate the effects of economic and political volatility on the taxation of corporate profits. In doing so we apply a theoretical framework - mainly based on Panteghini and Schjelderup [39] - that allows for investment irreversibility and for the ability of multinational companies (MNCs) to choose the optimal timing of foreign investment and to shift

\footnotetext{
${ }^{1}$ Such phenomenon is documented, among the others, by Markusen [32].

${ }^{2}$ For instance, Lee and Gordon [30], Devereux et al. [20] and Slemrod [43] report that in the 1980s the average top corporate tax rate was about $40 \%$. In the late 1990s, it fell to slightly more than $30 \%$. Moreover, while the statutory tax rate on corporate profits exceeded by $50 \%$ the average labour tax wedge in 1980, the two were roughly the same twenty years later (Haufler et al. [25]).
} 
profits by transfer pricing. In particular, this model suggests that higher volatility - interpreted either as the probability of receiving bad news or as the seriousness of the bad news (Bernanke [4]) - should induce governments to reduce their tax rates on corporate profits. The reason is that volatility reduces the overall number of foreign firms involved in foreign direct investment (FDI). Consequently, the optimal policy response to the reduction in a country's tax base consists in lowering the corporate tax rate in order to counteract the negative impact of increased volatility.

These predictions are tested on a panel data set of a large number of countries over the 1983-2003 period. First, a reduced-form dynamic equation of corporate tax rate determination is estimated by the generalised method of moments (GMM), where the top statutory corporate tax rate depends on a number of measures of economic and political volatility, along with a set of variables reflecting the size, underlying economic structure and degree of capital market openness in a country. Our results confirm the hypothesis that economic volatility is associated with lower top statutory corporate tax rates, while our indexes of political volatility - the frequency of changes in government and an index of the protection of property rights - do not appear to have any significant impact on corporate taxation policy.

In order to identify the channels through which volatility works, we also introduce a structural model that allows for simultaneous determination of the corporate tax rate and the FDI flow into a country. The estimates show that our measures of economic volatility significantly and negatively affect the corporate tax rate through their impact on the inflow of FDI to a country. Moreover, capital market openness has a negative effect on the level of the statutory corporate tax rate and a positive one on the size of FDI inflow.

The rest of the paper is organised as follows. Section $\mathbf{2}$ discusses the theoretical framework used to analyze the impact of volatility on FDI flow and corporate tax-rate setting strategies. Section 3 turns to the empirical implementation of the model by estimating a reduced-form dynamic equation 
of corporate tax rate determination, while section 4 tackles the structural model for simultaneous determination of the corporate tax rate and the flow of FDI into a country. Section 5 concludes.

\section{Theoretical framework}

A common feature of the standard theoretical tax competition literature is that capital investment is fully reversible or, alternatively, that capital investment is irreversible, although it is characterized by exogenous investment timing. Moreover, most of the theoretical contributions on tax competition disregard risk. ${ }^{3}$

As shown in Dixit and Pindyck [21], volatility has a negative impact on investment timing. This discouraging impact does not necessarily depend on risk aversion, but rather is due to the so-called Bad News Principle (BNP), ${ }^{4}$ according to which investment depends on the seriousness of bad news and its probability, but is independent of good news. Indeed, an increase in volatility means that good news gets better and bad news gets worse: since good news does not matter, increased volatility raises the threshold profit rate above which FDI is undertaken. Therefore, an increase in volatility delays FDI timing. This finding is in line with empirical evidence, which shows a negative relationship between uncertainty and FDI. In particular, Chen and So [10] showed that the 1997 Asian financial crisis (which caused an increase in exchange rate variability) discouraged FDI by US MNCs. Further evidence is provided by Aizenman and Marion [2], who focused on the foreign operations of US MCNs since 1989. They showed that uncertainty affects both vertical and horizontal FDI. In particular, they showed that greater supply uncertainty reduces the expected income from vertical FDI but increases the expected income from horizontal FDI. Greater demand uncertainty adversely affects the expected income under both production modes. Moreover, volatil-

\footnotetext{
${ }^{3}$ Exceptions are Gordon and Varian [23] and Lee [29].

${ }^{4}$ See Bernanke [4].
} 
ity and sovereign risk have a greater adverse impact on vertical FDI than on horizontal FDI. ${ }^{5}$

Applying the BNP, Panteghini and Schjelderup [39] model tax competition between two identical small open countries. In constructing the social welfare function for each country, they focus on the sum between profits (or equivalently, the producer surplus) generated by FDI and tax revenue from foreign firms' FDI in the home country. Hence, each government maximizes the welfare function, i.e.,

$$
\max _{\tau_{i}} W_{i} \quad i=A, B
$$

where $W_{i}$ is the intertemporal sum of overall gross profits for MNCs with a home base in country $i$ plus tax revenues from subsidiaries located in $i$ of MNCs with home base in country $j \neq i$. The maximization of $(1)$ is part of a sequential game, where at stage 1 each government sets its tax rate $\left(\tau_{i}\right)$; at stage 2 , the firms in country $A$ and $B$ decide whether to invest at time 0 or at time 1 .

Solving (1), Panteghini and Schjelderup [39] prove the existence of a symmetric Nash equilibrium tax rate, which equates at the margin the social cost of taxation to its social benefit. They then focus on the effects of market openness in this tax competitive setting. It is worth noting that market openness is negatively affected by the minimum size of the sunk costs needed to undertake FDI and is positively affected by the average profitability of investing firms. A fall in sunk costs may be related to globalization, as long as tighter economic integration causes a reduction in technical barriers such as national standards and other factors that lower investment costs. A rise in average profitability may also be linked to globalization and more specifically to the decrease in transportation costs as well as the formidable rise in skill-biased technology and information systems such as the Internet. ${ }^{6}$ It

\footnotetext{
${ }^{5}$ Further evidence is discussed in Markusen [32].

${ }^{6}$ Notice that information technology allows firms to outsource tasks to low-cost suppliers. Moreover, it has improved communications and thus decision making.
} 
is thus reasonable to expect that such factors have a positive effect on profit income. Along this line of reasoning Panteghini and Schjelderup [39] prove that:

Proposition 1 A decrease in size of the sunk cost needed to undertake FDI and/or an increase in profitability raises the equilibrium tax rate.

The reasoning behind proposition 1 is straightforward: a decrease in size of the sunk cost and/or an increase in profitability encourages FDI activities. This allows the two competing countries to set a higher tax without deterring FDI. Moreover, an improvement in business profitability raises the number of MNCs and thus widens the overall tax base. Hence, higher tax rates combined with wider tax bases in both countries yield larger tax revenue. ${ }^{7}$

Panteghini and Schjelderup [39] also examine the effect of income shifting on the equilibrium tax rate. They find that:

Proposition 2 A decrease in the cost of shifting profit decreases the equilibrium tax rate.

According to proposition 2, a decrease in the cost of income shifting makes income shifting less costly and thus stimulates tax competition: this induces governments to set lower tax rates. ${ }^{8}$

Empirical evidence shows that FDI and multinational firms are a significant part of economic output and investment in many countries. For this reason, the transmission of country-specific shocks by means of MNCs' activities is a phenomenon that deserves particular attention. Panteghini and Schjelderup [39] show that:

\footnotetext{
${ }^{7}$ These results are in line with Devereux et al. [19], who find a positive relationship between the extent of tax competition and the openness of countries.

${ }^{8}$ This result has an interesting policy implication as it helps to explain the widespread introduction of anti-avoidance rules: as long as governments can offset avoidance by raising its cost, they can set a higher tax rate. A similar point is made by Panteghini [37], who analyzes the relationship between MNCs' financial policies and governments' tax strategies.
} 
Proposition 3 Increased volatility lowers the equilibrium tax rates, and reduces tax revenue.

The reasoning behind proposition 3 is as follows. According to the BNP, an increase in volatility discourages FDI. This induces firms with an intermediate profitability to delay their investment decision. Thus the number of firms that immediately undertake FDI is less. Subsequently, however, only a fraction of the firms who delayed will receive good news and then invest. The remaining part of firms will decide not to invest. This means that an increase in volatility reduces the overall number of firms involved in FDI. The governments' policy response is therefore to lower the tax rate in order to partially offset the negative impact of increased volatility.

It is worth noting that a government's reputation may be a crucial determinant of fiscal policies. As shown by Panteghini [37]:

Proposition 4 An increase in the risk of expropriation by the government leads to a decrease in the equilibrium tax rate.

The reasoning behind proposition 4 is as follows: an increase in the risk of expropriation stimulates borrowing and allows MNCs to shift a greater amount of income. ${ }^{9}$ In order to offset the increase in income shifting opportunities, ${ }^{10}$ governments therefore tend to set lower tax rates. This means that an increase in credibility, i.e., a lower probability of expropriation, allows governments to set higher tax rates. ${ }^{11}$

These findings may help to explain the dynamics of capital income taxation. The fall in tax rates fits with the interpretation that the globalization process has led to increased volatility (proposition 3). However, the hypothesis that profits have become more volatile leads to a fall in tax revenue and

\footnotetext{
${ }^{9}$ On MNCs' financial strategies see e.g. Desai [15], [16], and Panteghini [37], [38].

${ }^{10}$ For a discussion on anti-avoidance rules see e.g. Garbarino and Panteghini [22]

${ }^{11}$ This point has some similarities with Cherian and Perotti [11], who showed that a gradual increase in reputation allows governments to attract a greater amount of FDIs.
} 
thus fails to explain the empirical findings of stable tax revenue over time (as does the entire tax competition literature). Such stability may be due to the second possible explanation offered in Panteghini and Schjelderup [39], namely the fall in trade barriers. As pointed out in proposition 1 , foreign markets open up in that more firms undertake FDI. This may offset the increase in volatility and make the net effect on tax revenue close to zero. A third determinant of tax rate changes is the cost of tax sheltering activities, which depend on anti-avoidance rules, consulting expenses, and transaction costs (proposition 2). Whenever the reduction in transaction and (tax and financial) consultancy costs overcomes the negative effect of more stringent anti-avoidance rules, it is natural to expect a tax rate cut. Finally, an increase in the government's reputation may lead to a rise in the statutory corporate tax rate (proposition 4).

\section{Empirical implementation}

The empirical predictions of the theoretical model outlined in section $\mathbf{2}$ are tested on a large panel data set of countries in the time span 1983-2003. We start by estimating a standard reduced-form equation to determine the corporate tax rate and turn in the next section to estimate a structural model where the tax rate and the tax base (the inflow of FDI) are determined simultaneously.

\subsection{Reduced form corporate tax rate equation}

First, in order to explore the impact of capital market openness and various volatility measures on the corporate tax rate setting process, let us estimate a dynamic reduced form equation such as (2) below:

$$
\tau_{i t}=\rho \tau_{i t-1}+x_{i t}^{\prime} \beta+v_{i t}^{\prime} \gamma+f_{i}+h_{t}+\varepsilon_{i t}
$$


where the corporate tax setting policy of country $i$ in period $t$ is represented by $\tau_{i t}$. Since the relevant tax rate in explaining the profit shifting-motivated decisions of MNCs is the statutory rate, here we use a country's top statutory corporate income tax rate as the dependent variable.

By estimating the corporate tax setting equation (2), we aim at finding whether, after controlling for a number of structural determinants of corporate tax setting policy $\left(x_{i t}\right)$, various measures of economic and political volatility (vector $v_{i t}$ ) have an impact on the corporate tax rate. Indeed, countries in which economic, social and political fundamentals are highly volatile and uncertain should have an increase in the outflow of domestic firms and a decrease in the inflow of FDI. Volatility should therefore act, by means of tax base adjustments, on the level of the corporate tax rate.

Equation (2) includes among regressors a one-period lag of the corporate tax rate $\left(\tau_{i t-1}\right)$ in order to take into account the high degree of persistency in the corporate tax rate that is typically observed. The model also includes time effects $\left(h_{t}\right)$ in order to capture the influence of time-specific common shocks, and country specific fixed effects $\left(f_{i}\right)$ to account for country characteristics that are constant over time (such as geographic location).

Following recent empirical literature in this area (Slemrod [43], Winner [45], Haufler et al. [25]), the set of control variables $x_{i t}$ in the corporate tax setting equation (2) includes country size, an index of capital mobility, government spending, the rate of employment, the demographic structure of the population and the level of personal income tax. Country size is measured by GDP. ${ }^{12}$ We can expect a positive effect of GDP on the corporate tax rate. ${ }^{13}$

Secondly, the degree of capital mobility might be a relevant factor to explain FDI decisions by MNCs. Now, an often invoked reason for the apparent decline of tax rates on profits is that firms can choose the location of their

\footnotetext{
${ }^{12}$ It should be noticed that GDP might also be a proxy for the size of the corporate income tax base. Consequently, when estimating equation (2) we allow for potential endogeneity of the GDP variable with respect to corporate taxation policy.

${ }^{13}$ See Bucovetsky [8], Wilson [44] and Haufler and Wooton [26].
} 
plants in order to reduce the amount of tax paid to governments. Governments that impose restrictions on capital flow should face an inelastic tax base and should consequently be able to set higher tax rates than open countries. Measuring the actual degree of capital openness of a country, though, is a rather difficult task (Winner [45]). Slemrod [43] employs the discrete Sachs-Warner index of trade openness, that, however, is only an imperfect proxy for the actual degree of capital mobility. Other indicators - such as the stock of foreign FDI in a country - are not suitable measures either, because, by changing sluggishly over time, they tend to capture other time-invariant aspects of a country that make it an attractive destination for foreign investors (such as its size and human capital stock). In the empirical work, we therefore use the Chinn and Ito [12] index of capital market openness that is based on the legal restrictions imposed on the international mobility of capital and firms. ${ }^{14}$

Equation (2) also includes a measure of government expenditure: since tax revenues are used to finance public expenditure, the degree of public consumption could be an important element to explain the corporate tax rate of a country. There is some evidence, though, that the statutory tax rate is not significantly correlated with the fiscal needs of the government (Slemrod [43]). Some authors (Haufler et al. [25]) even found that the amount of public expenditure influences negatively the corporate income tax rate. ${ }^{15}$ Therefore, the sign of the coefficient on public spending is a priori ambiguous. We use the ratio of government expenditure to GDP as a measure of public sector intervention.

\footnotetext{
${ }^{14}$ The Chinn and Ito [12] capital openness indicator is based on data taken from the IMF Annual Report on Exchange Arrangements and Exchange Restrictions. While similar to the Quinn [40] index of capital mobility, we use the Chinn and Ito index because it is more up-to-date (it covers the period 1970-2004, while the Quinn index is available only up to 1999 for some countries and 1997 for others) and for a larger subset of countries (181 against the 90 of the Quinn Index). See also Chinn and Ito [13]

${ }^{15}$ They interpret this result with the argument that high-spending countries reveal a stronger preference for public goods. To sustain the welfare state, therefore, policy-makers have to reduce their tax rates in order not to induce an outflow of firms and tax base.
} 
In addition, equation (2) includes the employment rate (total employment over total population) as a measure of the size of the labour tax base, and the proportion of young (below age 14) and elderly (above age 65) population to account for potential demographic pressures on tax revenue requirements.

Finally, equation (2) includes the (top) personal income tax rate: according to the so-called "backstop hypothesis" (Slemrod [43]), one of the key reasons for taxing corporate income is to prevent citizens from avoiding personal taxation by incorporating their income. As a result, the statutory corporate tax rate should be higher in countries where the top personal income tax rate is high.

\subsection{Measures of volatility}

In addition, equation (2) includes a number of economic and political volatility indicators among regressors.

\subsubsection{Economic volatility}

As far as economic volatility is concerned, the usual strategy is to calculate the standard deviation of the relevant variables along intervals of 5 or 10 years. ${ }^{16}$ In our framework, though, that strategy would be pretty costly in terms of data loss. Consequently, in order to fully exploit the information contained in our data set, we calculate the standard deviation of the relevant variable through the five previous years. For example, in order to calculate the volatility of the interest rate in year 2000, we calculate the standard deviation of the interest rates from 1996 to 2000. As a result, this measure amounts to a kind of "moving average" index of volatility. This measure is calculated for three economic variables: GDP growth rate, real interest rate and nominal exchange rate.

\footnotetext{
${ }^{16}$ Notice that this strategy is employed, in particular, in the growth literature that studies the impact of volatility and uncertainty on GDP growth rates. See, e.g, Ramey and Ramey [41] and Aghion et al. [1].
} 
Firstly, GDP is a measure of the aggregate income of a country and of the size of the market. The literature on FDI (see e.g. Markusen [32]) reports evidence that the horizontal-type multinational - i.e., multinationals that sell their products to the host country's customers - is the most widespread form of multinational enterprise among OECD countries. It is therefore reasonable to expect that, coeteris paribus, MNCs prefer to settle in stable and expanding markets, especially when the investment choice is to some extent irreversible. This finding is in line with Panteghini and Schjelderup [39].

Secondly, interest rate volatility might be important in the light of the role of the tax system in shaping the financial structure of firms. This is due to the fact that interest expenses are usually deductible from corporate taxable income, and offer MNCs a tax shield by making use of both the internal (through the so called "debt shifting" between affiliates) and external credit market. ${ }^{17}$ As a result, real interest rate variability could have a number of effects on MNCs' strategies. First, it could require multinational firms that invest in uncertain countries to continuously adjust the optimal debt/asset ratio in response to the changing credit market conditions. Second, MNCs that invest in uncertain environments could be forced to change their internal/external debt strategy in response to external credit market conditions of the foreign affiliates. Third, MNCs that use the internal credit market channel can shift profits and tax burden from one country to another by using the debt shifting option. However, an arm's length interest rate is typically used by fiscal authorities in order to calculate the fiscal burden on firms. Uncertainty in interest rates applicable to "between affiliates" debt shifting transactions could then affect the feasibility and profitability of such

\footnotetext{
${ }^{17}$ In particular, external credit market conditions proved to be important determinants of the financial structure of multinationals'affiliates in developed credit markets countries (see Desai et al. [18]) and for partly foreign-owned firms (see Mintz and Weichenrieder [36]). Moreover, as shown in Desai et al. [18], multinational affiliates substitute external and internal debt according to the evolution of credit market conditions.
} 
profit shifting strategies.

Finally, in line with Chen and So [10], we use the exchange rate volatility as a measure of the variability of the relative price of domestic and foreign goods.

\subsubsection{Political volatility}

Vector $v_{i t}$ in equation (2) also includes two measures of "political uncertainty."

First, we account for changes in a government's policy by a variable reporting the number of changes of a country's government over the previous five years (see the Appendix for details). Since changes in government composition are often associated with relevant policy changes, this variable should capture the degree of stability of policy orientation of a country's government.

Second, we control for private property protection using an indicator (ranging from 0 to 10) that measures the degree of private property protection and consequently the probability of expropriation. ${ }^{18}$

Descriptive statistics and data sources of all variables used in the analysis are reported in the Appendix.

\subsection{Results}

Equation (2) is estimated on the unbalanced panel data set described in the Appendix, using the GMM estimator developed by Arellano and Bond [3]. After taking first differences of equation (2) to eliminate the country fixed effects, the Arellano-Bond estimator uses twice and more lagged values of $\tau$ as instruments for the lagged dependent variable in the first-differenced equation, under the hypothesis that first-order serial correlation in the residuals of the equation in levels is nil.

\footnotetext{
${ }^{18}$ Using an index of "social conflict" measuring the degree of social tension in a country (including various symptoms of social unrest, such as strikes, anti-government demonstrations, political assassinations and riots) and the probability of an abrupt change in government's policy and compostion gave very similar results.
} 
Moreover, using a GMM approach we also control for potential endogeneity of other right hand side variables (in particular, government spending, GDP and personal income tax rate). The matrix of instruments includes all of the exogenous variables as well as their lags.

The GMM estimation results of equation (2) are shown in tables 1 and 2. The Arellano and Bond [3] tests for the presence of auto-correlation in the residuals reject the null hypothesis of no first-order autocorrelation and cannot reject the null hypothesis of no second-order autocorrelation. This suggests that twice-lagged values of $\tau$ are valid instruments for $\Delta \tau_{i t-1}$. Instrument validity is also confirmed by the Hansen test results reported at the bottom of tables 1 and 2. Finally, the standard errors shown in the table are robust to the presence of auto-correlation and heteroschedasticity.

Table 1, column (a), reports the estimation results of a standard specification including no volatility measure; column (b) shows the estimates when the five-year standard deviation of real interest rate (measured by the prime lending rate minus the inflation rate) is included in the equation as a measure of "economic" volatility. Column (c) also adds the two "political" volatility indicators: the index of property rights protection and the number of changes in government over the previous five years.

Similarly to earlier studies, the auto-regressive coefficient on the lagged dependent variable shows a high degree of persistence of the statutory corporate tax rate, with an auto-regressive coefficient of about 0.9. As far as the control variables are concerned, all have the expected sign: larger countries in terms of GDP size - as well as those with higher percentages of young and old population - appear to set higher corporate tax rates, while government spending and employment are estimated imprecisely. Moreover, neither the level of the personal income tax rate nor the index of capital market openness are statistically significant. Overall, the results are similar to those obtained in Slemrod [43], where fixed-effects estimation leaves a large fraction of the time-series variance of the corporate tax rate unexplained. 
Table 1 Reduced-form corporate tax rate determination equation (I)

\begin{tabular}{|c|c|c|c|}
\hline & \multicolumn{3}{|c|}{$\tau_{i t}$} \\
\hline & (a) & (b) & (c) \\
\hline$\tau_{i t-1}$ & $0.911(0.034)^{* * *}$ & $0.898(0.047)^{* * *}$ & $0.906(0.043)^{* * *}$ \\
\hline openness & $-0.062(0.074)$ & $-0.063(0.117)$ & $-0.052(0.095)$ \\
\hline GDP & $1.606(0.661)^{* *}$ & $0.940(0.508)^{*}$ & $0.931(0.467)^{* *}$ \\
\hline public spending & $-0.013(0.015)$ & $-0.016(0.013)$ & $-0.007(0.013)$ \\
\hline personal income tax & $0.004(0.015)$ & $-0.003(0.021)$ & $-0.012(0.014)$ \\
\hline employment & $-1.761(1.878)$ & $-2.206(2.855)$ & $-1.294(2.170)$ \\
\hline$\%$ old & $0.119(0.045)^{* * *}$ & $0.099(0.040)^{* *}$ & $0.100(0.033)^{* * *}$ \\
\hline$\%$ young & $0.056(0.021)^{* * *}$ & $0.056(0.030)^{*}$ & $0.051(0.019)^{* * *}$ \\
\hline VOLATILITY & & & \\
\hline real interest rate & & $-0.105(0.043)^{* *}$ & $-0.112(0.037)^{* * *}$ \\
\hline property rights & & & $-0.090(0.081)$ \\
\hline political & & & $-0.062(0.128)$ \\
\hline observations & 1646 & 1153 & 1133 \\
\hline countries & 114 & 89 & 87 \\
\hline time effects & yes & yes & yes \\
\hline fixed effects & yes & yes & yes \\
\hline $\begin{array}{c}\text { Hansen test } \\
(p \text { value })\end{array}$ & $\begin{array}{c}\varkappa_{57}^{2}=59.17 \\
(0.396)\end{array}$ & $\begin{array}{c}\varkappa_{55}^{2}=51.14 \\
(0.623)\end{array}$ & $\begin{array}{c}\varkappa_{55}^{2}=45.90 \\
(0.776)\end{array}$ \\
\hline $\begin{array}{l}\mathrm{AR}(1) \text { test } \\
(p \text { value })\end{array}$ & $\begin{array}{c}z=-4.92 \\
(0.000)\end{array}$ & $\begin{array}{c}z=-4.13 \\
(0.000)\end{array}$ & $\begin{array}{c}z=-4.14 \\
(0.000)\end{array}$ \\
\hline $\begin{array}{l}\mathrm{AR}(2) \text { test } \\
(p \text { value })\end{array}$ & $\begin{array}{c}z=0.48 \\
(0.628)\end{array}$ & $\begin{array}{c}z=0.41 \\
(0.682)\end{array}$ & $\begin{array}{c}z=0.37 \\
(0.714)\end{array}$ \\
\hline
\end{tabular}

Notes

1) dependent variable: top statutory corporate income tax rate;

2) robust standard errors in parentheses;

$3) *, * *, * * *$ : significant at $10 \%, 5 \%, 1 \%$;

4) the Arellano-Bond test for an $\operatorname{AR}(1) / \operatorname{AR}(2)$ error process in the equation in first differences is distributed as a standard normal $z(0,1)$;

$5)$ the Hansen test of overidentifying restrictions $(k)$ is distributed as $\varkappa^{2}{ }_{k}$. 
Table 2 Reduced-form corporate tax rate determination equation (II)

\begin{tabular}{|c|c|c|c|}
\hline & \multicolumn{3}{|c|}{$\tau_{i t}$} \\
\hline & (d) & (e) & (f) \\
\hline$\tau_{i t-1}$ & $0.916(0.043)^{* * *}$ & $0.910(0.038)^{* * *}$ & $0.904(0.043)^{* * *}$ \\
\hline openness & $-0.065(0.089)$ & $-0.079(0.076)$ & $-0.062(0.091)$ \\
\hline GDP & $1.402(0.553)^{* *}$ & $2.931(1.213)^{* *}$ & $3.423(1.144)^{* * *}$ \\
\hline public spending & $-0.013(0.012)$ & $-0.016(0.016)$ & $-0.019(0.010)^{*}$ \\
\hline personal income tax & $-0.003(0.016)$ & $-0.001(0.014)$ & $-0.005(0.017)$ \\
\hline employment & $-2.072(2.184)$ & $-2.511(2.644)$ & $-2.692(2.712)$ \\
\hline$\%$ old & $0.154(0.061)^{* *}$ & $0.130(0.047)^{* * *}$ & $0.130(0.041)^{* * *}$ \\
\hline$\%$ young & $0.064(0.027)^{* *}$ & $0.055(0.018)^{* * *}$ & $0.058(0.020)^{* * *}$ \\
\hline \multicolumn{4}{|l|}{ VOLATILITY } \\
\hline nominal exchange rate & & $-0.967(0.288)^{* * *}$ & $-1.067(0.302)^{* * *}$ \\
\hline GDP growth rate & $-0.005(0.040)$ & & \\
\hline property rights & $-0.032(0.081)$ & & $0.017(0.065)$ \\
\hline political & $-0.661(0.685)$ & & $-0.128(0.137)$ \\
\hline observations & 1496 & 1611 & 1504 \\
\hline countries & 99 & 113 & 99 \\
\hline time effects & yes & yes & yes \\
\hline fixed effects & yes & yes & yes \\
\hline $\begin{array}{c}\text { Hansen test } \\
(p \text { value })\end{array}$ & $\begin{array}{c}\varkappa_{59}^{2}=58.42 \\
(0.497)\end{array}$ & $\begin{array}{c}\varkappa_{60}^{2}=56.34 \\
(0.610)\end{array}$ & $\begin{array}{c}\varkappa_{59}^{2}=54.49 \\
(0.642)\end{array}$ \\
\hline $\begin{array}{l}\text { AR }(1) \text { test } \\
(p \text { value })\end{array}$ & $\begin{array}{c}z=-4.69 \\
(0.000)\end{array}$ & $\begin{array}{c}z=-4.94 \\
(0.000)\end{array}$ & $\begin{array}{c}z=-4.83 \\
(0.000)\end{array}$ \\
\hline $\begin{array}{c}\mathrm{AR}(2) \text { test } \\
(p \text { value })\end{array}$ & $\begin{array}{c}z=-0.37 \\
(0.714)\end{array}$ & $\begin{array}{c}z=0.08 \\
(0.936)\end{array}$ & $\begin{array}{c}z=-0.00 \\
(0.998)\end{array}$ \\
\hline
\end{tabular}

Notes

1) dependent variable: top statutory corporate income tax rate;

2) robust standard errors in parentheses;

$3) *, * *, * * *$ : significant at $10 \%, 5 \%, 1 \%$;

4) the Arellano-Bond test for an $\operatorname{AR}(1) / \operatorname{AR}(2)$ error process in the equation in first differences is distributed as a standard normal $z(0,1)$;

$5)$ the Hansen test of overidentifying restrictions $(k)$ is distributed as $\varkappa^{2}{ }_{k}$. 
As far as our volatility indicators are concerned, the standard deviation of the real interest rate has a significant and negative effect on the corporate tax rate. This result is in line with the theoretical predictions of section $\mathbf{2}$, in the sense that, since volatility reduces the overall number of firms involved in FDI activities, a government's optimal policy response consists in lowering the corporate tax rate in order to partially offset the negative impact of increased volatility. On the other hand, the indexes of political volatility, while having the expected negative sign, are not estimated at having a significant impact on corporate taxation policy.

Table 2, column (d), shows the results when using the standard deviation of the GDP growth rate as a measure of economic volatility, while columns (e) and (f) use the standard deviation of the nominal exchange rate as a measure of economic volatility. The results show that the nominal exchange rate volatility has a negative and significant impact, while the political uncertainty variables and GDP growth rate volatility are not estimated at having any significant effect on the corporate tax rate.

\section{Structural model estimation}

While an estimate of the corporate tax equation (2) supports the hypothesis that economic volatility measured by the interest rate and exchange rate variability plays a role in the corporate tax setting process, it is unable to reveal how volatility works. In fact, the corporate tax determination equation can be thought of as a reduced form of a two-equation structural model. Similarly to the specification used in Brett and Pinkse [7], the structural form specification comprises a tax base determination equation that models the tax base (the FDI inflow in our case) as a function of a given set of exogenous variables including our measures of volatility, as well as the corporate tax rate. Secondly, the empirical model includes the tax rate setting equation, where the corporate tax rate is regressed on a set of variables that includes 
the endogenously determined size of the tax base.

In particular, we can verify whether the volatility measures that proved to be significant determinants of corporate taxation policy exert their effect through the FDI flow into a country, and whether a country's policy-makers react to changes in the tax bases by manoeuvring the tax rates. Indeed, according to the theoretical model outlined in section $\mathbf{2}$, we should expect volatility variables to influence negatively the FDI inflow, while the statutory tax rate should be positively correlated with the net inflow of FDI.

As a result, the structural form we employ is made up of the following two equations, where the corporate tax rate $\left(\tau_{i t}\right)$ and the tax base (FDI flow, $b_{i t}$ ) are determined simultaneously:

$$
\begin{aligned}
& \tau_{i t}=\rho \tau_{i t-1}+\alpha b_{i t}+x_{i t}^{\prime} \beta+f_{i}+h_{t}+\varepsilon_{i t} \\
& b_{i t}=z_{i t}^{\prime} \delta+v_{i t}^{\prime} \phi+\kappa \tau_{i t-1}+g_{i}+m_{t}+\eta_{i t}
\end{aligned}
$$

In equation (3), the top statutory corporate tax rate depends on its own lag $\left(\tau_{i t-1}\right)$ and on a vector of variables $\left(x_{i t}\right)$ including demographic composition of the population, rate of urbanization, public spending as a share of GDP, employment rate, personal income tax rate and the logarithm of the size of FDI outflows. ${ }^{19}$ Moreover, equation (3) includes the logarithm of the FDI inflow $\left(b_{i t}\right)$ through parameter $\alpha$.

The logarithm of the FDI inflow $b_{i t}$ appears as the dependent variable in equation (4), where it depends on a set of exogenous variables $\left(z_{i t}\right)$, on our volatility measures $\left(v_{i t}\right)$ and on the lagged statutory tax rate $\left(\tau_{i t-1}\right)$, based on the assumption that FDI flow adjusts to changes in the corporate taxation policy with a one-year lag. ${ }^{20}$ The vector $z_{i t}$ includes a number of variables that should capture the attractiveness of a location for FDI: the duration of

\footnotetext{
${ }^{19}$ Apart from demographics and urbanization rate, all other variables are allowed to be endogenous.

${ }^{20}$ Using the contemporaneous statutory tax rate made identification of the parameters more difficult, while not leading to substantially different results.
} 
education of people aged 25 and more as an index of human capital endowment of a country, an index of infrastructure endowment represented by the ratio of the length of the road and railway network over the area of a country, and an index of productivity (GDP per worker). ${ }^{21}$ Finally, both equations include GDP and the Chinn-Ito index of capital market openness.

The model is estimated by three stage least squares (3SLS) and both equations include time $\left(h_{t}, m_{t}\right)$ and country $\left(f_{i}, g_{i}\right)$ fixed effects. The results found by using the standard deviation of the real interest rate as a measure of economic volatility are reported in table $3 .^{22}$ In order to allow for the fact that FDI inflow might affect the volatility of the real interest rate, we treat it as endogenous by using its own lags as well as the five-year standard deviation of savings and nominal exchange rate as instruments. On the other hand, the two political volatility variables are taken as exogenous.

The equation (4) reveals that the lagged statutory corporate tax rate has a negative and statistically significant effect on the size of FDI flowing into a country. Moreover, the economic volatility variable is estimated in having a negative and significant impact on FDI: at mean values, the implied elasticity of FDI compared to the interest rate volatility equals around -0.7 . Coherently with the reduced form estimates, political volatility indicators, while having the expected negative sign, are not estimated to have a significant role in the tax base determination process.

As far as other variables are concerned, the measures of human capital, infrastructure endowment and productivity do not appear to influence the FDI inflow. While these results might be explained by the fact that those variables are measured with an error and fail to properly capture a country's attractiveness for foreign investment, they are compatible with the hypothesis that profit shifting is the leading force driving FDI flow. In neither case, the backstop hypothesis is supported by our findings.

\footnotetext{
${ }^{21}$ See de Mooij and Ederveen [14] for a review of the empirical literature on the determinants of FDI.

${ }^{22}$ Similar results emerge when using the nominal exchange rate volatility.
} 
Table 3 Structural-form model: FDI and corporate tax rate

\begin{tabular}{|c|c|c|}
\hline & $\tau_{i t}$ & $b_{i t}$ \\
\hline$\tau_{i t-1}$ & $0.742(0.229)^{* * *}$ & $-0.099(0.048)^{* *}$ \\
\hline$b_{i t}$ & $2.292(0.900)^{* *}$ & \\
\hline human capital & & $-0.025(0.386)$ \\
\hline infrastructure & & $-0.070(1.204)$ \\
\hline productivity & & $-0.086(0.100)$ \\
\hline GDP & $1.162(2.722)$ & $0.998(5.978)$ \\
\hline openness & $-1.602(0.520)^{* * *}$ & $0.240(0.100)^{* *}$ \\
\hline$\%$ old & $-0.205(2.013)$ & \\
\hline$\%$ young & $-0.210(1.330)$ & \\
\hline urbanization & $-0.162(0.643)$ & \\
\hline public spending & $0.210(1.079)$ & \\
\hline employment & $0.278(1.884)$ & \\
\hline personal income tax & $0.217(0.174)$ & \\
\hline FDI outflow & $-1.979(1.085)^{*}$ & \\
\hline \multicolumn{3}{|l|}{ VOLATILITY } \\
\hline real interest rate & & $-0.125(0.037)^{* * *}$ \\
\hline property rights & & $-0.190(0.141)$ \\
\hline political & & $-0.014(0.100)$ \\
\hline observations & \multicolumn{2}{|c|}{462} \\
\hline countries & \multicolumn{2}{|c|}{51} \\
\hline Hansen-Sargan test ( $p$ value) & \multicolumn{2}{|c|}{0.73} \\
\hline time effects & yes & yes \\
\hline fixed effects & yes & yes \\
\hline
\end{tabular}

\section{Notes}

1) dependent variables: $\tau_{i t}=$ top statutory corporate income tax rate; $b_{i t}=$ $\log ($ FDI inflow);

2) robust standard errors in parentheses;

3) the Hansen-Sargan test of overidentifying restrictions is distributed as $\chi_{(30)}^{2}$;

4) $*, * *, * * *$ : significant at $10 \%, 5 \%, 1 \%$. 
Estimation of the tax rate determination equation that explicitly includes FDI on the right hand side shows that the latter variable has the expected positive and significant impact on the corporate tax rate. This confirms the model predictions. Unlike the reduced form specification, the Chinn-Ito measure of capital openness now has the expected negative impact on the corporate tax rate, consistent with the view that opening up an economy enhances the competitive downward pressure on tax rates. It is remarkable that the openness variable is estimated in having a positive effect on the inflow of FDI: this suggests that the small importance of this variable when estimating the reduced form tax setting equation might be due to the fact that the two opposite effects of the capital openness measure on FDI and tax rates respectively tend to cancel each other out.

Overall, the evidence from the estimate of the structural model suggests that the degree of volatility as well as the extent of capital market openness affect FDI flow and corporate tax setting. In particular, our results suggest that economic volatility tends to inhibit FDI inflow and, by reducing the available tax base, it exerts a negative effect on the level of the corporate tax rate.

\section{Concluding remarks}

This article is based on a theoretical framework that allows for irreversibility in the investment decision of MNCs and for the possibility of profit shifting via transfer pricing. Thus it has explored the role of capital market openness and political and economic volatility on FDI flow and corporate tax rate determination. The empirical analysis, based on a large panel data set of countries over the 1983-2003 period, gives the following main results. First, when a reduced-form dynamic equation of corporate tax rate determination is estimated by the generalised method of moments (GMM), the top statutory corporate tax rate is estimated to be negatively and significantly affected by 
economic volatility. On the other hand, the indicators of political volatility and capital market openness, while having the expected sign, do not have a significant impact on corporate taxation policy. Second, when estimating a structural model that allows for simultaneous determination of the corporate tax rate and the flow of FDI into a country, it turns out that a country's degree of capital market openness is important to determine FDI inflow and set corporate tax rates, and that economic volatility tends to affect the corporate tax rate through its negative impact on FDI inflow.

\section{References}

[1] Aghion, P., G. Angeletos, A. Banerjee and K. Manova (2005), Volatility and Growth: Credit Constraints and Productivity-enhancing Investment, NBER Working Paper No. 11349.

[2] Aizenman, J. and N. Marion (2004), The Merits of Horizontal versus Vertical FDI in the Presence of Uncertainty, Journal of International Economics, 62, pp. 125-148.

[3] Arellano, M. and S. Bond (1991) Some Tests of Specification for Panel Data; Monte Carlo Evidence and an Application to Employment Equations, Review of Economic Studies, 58, pp. 277-297.

[4] Bernanke, B.S. (1983), Irreversibility, Uncertainty, and Cyclical Investment, Quarterly Journal of Economics, 98, pp. 85-103.

[5] Blundell, R. and S. Bond (1998), Initial Conditions and Moment Restrictions in Dynamic Panel Data Models, Journal of Econometrics, 87, pp. 115-143.

[6] Bretschger, L. and F. Hettich (2002) Globalisation, Capital Mobility and Tax Competition: Theory and Evidence for OECD Countries, European Journal of Political Economy, 18, pp. 695-716. 
[7] Brett, C. and J. Pinkse (2000) The Determinants of Municipal Tax Rates in British Columbia, Canadian Journal of Economics, 33, pp. 695-714.

[8] Bucovetsky, S. (1991) Asymmetric Tax Competition, Journal of Urban Economics, 30, pp. 167-181.

[9] Calderon, C. and L. Servén (2004), The Effects of Infrastructure Development on Growth and Income Distribution, World Bank Working Paper WPS3400.

[10] Chen, C. and R.W. So (2002), Exchange Rate Variability and the Riskiness of US Multinational Firms: Evidence from the Asian Financial Turmoil, Journal of Multinational Financial Management, 12, pp. 411428.

[11] Cherian, J.A. and E. Perotti (2001), Option Pricing and Foreign Investment under Political Risk, Journal of International Economics, 55, pp. 359-377.

[12] Chinn, M. and I. Ito (2002), Capital Account Liberalization, Institutions and Financial Development: Cross-country Evidence, NBER Working Paper No. 8967.

[13] Chinn, M. and I. Ito (2005), What Matters for Financial Development? Capital Controls, Institutions, and Interactions, NBER Working Paper No. 11370.

[14] de Mooij, R. and S. Ederveen (2003), Taxation and Foreign Direct Investment: A Synthesis of Empirical Research, International Tax and Public Finance, 10, pp. 673-693.

[15] Desai, M.A. (2003), The Divergence between Book Income and Tax Income, Tax Policy and the Economy, 17, pp. 169-206, Cambridge: MIT Press for the National Bureau of Economic Research. 
[16] Desai, M.A. (2005), The Degradation of Reported Corporate Profits, Journal of Economic Perspectives, 12, pp. 171-192.

[17] Desai, M.A. and F.C. Foley (2004), The Comovement of Returns and Investment within the Multinational Firm, NBER Working paper No. 10785 .

[18] Desai, M.A., F.C. Foley, and J.R. Jr. Hines (2004), A Multinational Perspective on Capital Structure Choice and Internal Capital Markets, Journal of Finance, 59, pp. 2451-2487.

[19] Devereux, M.P., B. Lockwood, and M. Redoano (2002), Do Countries Compete over Corporate Tax Rates? CEPR Working Paper No. 3400.

[20] Devereux, M.P, R. Griffith and A. Klemm (2002), Corporate Income Tax Reforms and International Tax Competition, Economic Policy: A European Forum, 17, pp. 450-495.

[21] Dixit, A. and R.S. Pindyck (1994), Investment under Uncertainty, Princeton University Press.

[22] Garbarino, C. and P.M. Panteghini (2007), Corporate Taxation in Europe: Competitive Pressure and Cooperative Targets, in Gregoriou, G.N. and C. Read (eds.), International Taxation, Elsevier, forthcoming.

[23] Gordon, R.H. and H.R. Varian (1989), Taxation of Asset Income in the Presence of a World Securities Market, Journal of International Economics, 26, pp. 205-226.

[24] Haufler, A. and G. Schjelderup (2000), Corporate Tax Systems and Cross Country Profit Shifting, Oxford Economic Papers, 52, pp. 306325. 
[25] Haufler, A., A. Klemm and G. Schjelderup (2006), Globalization and the Optimal Mix of Wage and Profit Taxes, CESifo Working Paper No. 1678.

[26] Haufler, A. and I. Wooton (1999), Country Size and Tax Competition for Foreign Direct Investment, Journal of Public Economics, 71, pp.121139.

[27] Hines, J.R. (1999), Lessons from Behavioral Responses to International Taxation, National Tax Journal, 52, pp. 304-322.

[28] La Porta F., F. Lopez-De-Silanes, A. Shleifer, and R.W. Vishny (1997), Legal Determinants of External Finance, Journal of Finance, 52, pp. 1131-1150.

[29] Lee, K. (2004), Taxation of Mobile Factors as Insurance under Uncertainty, Scandinavian Journal of Economics, 106, pp. 253-271.

[30] Lee, Y. and R. Gordon (2005), Tax Structure and Economic Growth, Journal of Public Economics, 89, pp. 1027-1043.

[31] Leland, H.E. (1994), Corporate Debt Value, Bond Covenants, and Optimal Capital Structure, Journal of Finance, 49, pp. 1213-1252.

[32] Markusen, J. (2002), Multinational Firms and the Theory of International Trade, MIT Press, Cambridge.

[33] Mills, L.F. and K.J. Newberry (2004), Do Foreign Multinational's Tax Incentives Influence Their U.S. Income Reporting and Debt Policy?, National Tax Journal, 57, pp. 89-107.

[34] Mintz, J. (2000), Reforming the Tax Cut Agenda, Canadian Tax Journal, 48, pp. 689-709. 
[35] Mintz, J. and M. Smart (2004), Income Shifting, Investment, and Tax Competition: Theory and Evidence from Provincial Taxation in Canada, Journal of Public Economics, 88, pp. 1149-1168.

[36] Mintz, J. and A.J. Weichenrieder (2005), Taxation and the Financial Structure of German Outbound FDI, CESifo Working Paper No. 1612.

[37] Panteghini, P.M. (2006), The Capital Structure of Multinational Companies under Tax Competition, CESifo Working Paper No. 1721.

[38] Panteghini, P.M. (2007), Corporate Taxation in a Dynamic World, Springer-Verlag, forthcoming.

[39] Panteghini, P.M. and G. Schjelderup (2006), To Invest or not to Invest: A Real Options Approach to FDIs and Tax Competition, International Tax and Public Finance, 13, pp. 643-660.

[40] Quinn, D. (1997), The Correlates of Change in International Financial Regulation, American Political Science Review, 91, pp. 531-552.

[41] Ramey G. and V.A. Ramey (1995), Cross Country Evidence on the Link between Volatility and Growth, American Economic Review, 85, pp. 1138-1151.

[42] Rodrik D. (1997), Has Globalization Gone Too Far?, Institute for International Economics, Washington, D.C.

[43] Slemrod, J. (2004), Are Corporate Tax Rates or Countries Converging?, Journal of Public Economics, 88, pp. 1169-1186.

[44] Wilson, J.D. (1991) Tax Competition with Interregional Differences in Factor Endowments, Regional Science and Urban Economics, 21, pp. 423-451. 
[45] Winner, H. (2005), Has Tax Competition Emerged in OECD Countries? A Panel Data Approach, International Tax and Public Finance, 12, pp. $667-687$. 


\section{Appendix}

\section{Baseline full sample of countries (114 countries). Longest time period: 1983-2003 (unbalanced panel).}

Argentina $^{\#}$, Australia\# , Austria, Azerbaijan, Bahamas, Bahrain\# , Bangl-

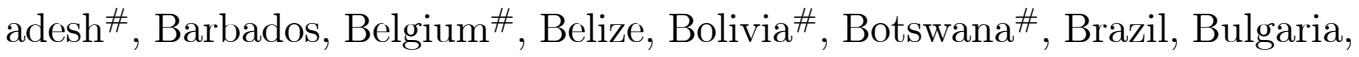
Cambodia, Cameroon, Canada\# ${ }^{\#}$ Chile\# ${ }^{\#}$ China, Colombia\#, Congo (Republic of), Costa Rica\#, Cote d'Ivoire, Croatia, Cyprus\#, Czech Republic, Denmark ${ }^{\#}$, Dominican Republic, Ecuador\#, Egypt\#, El Salvador, Estonia, Fiji, Finland" ${ }^{\#}$ France\#, Gabon, Germany\#, Ghana, Greece, Guatemala\# , Haiti, Honduras, Hong Kong, Hungary\#, Iceland, India\#, Indonesia\# ${ }^{\#}$ Iran, Ireland ${ }^{\#}$, Israel ${ }^{\#}$, Italy\#, Jamaica\#, Japan\# ${ }^{\#}$ Kazakhstan, Kenya\#, Republic of Korea, Kuwait, Latvia, Liberia, Lithuania, Malawi, Malaysia\#, Malta, Mauritius ${ }^{\#}$, Mexico\#, Morocco, Mozambique, Namibia, Netherlands\# ${ }^{\#}$ Netherlands Antilles, New Zealand\#, Nicaragua, Nigeria, Norway\#, Oman, Pakistan, Panama\#, Papua New Guinea\#, Paraguay\#, Perü, Philippines\#, Poland\# , Portugal\# , Qatar, Romania, Russia, Saudi Arabia, Senegal, Singapore\# ${ }^{\#}$ Slovak Republic, Slovenia, Solomon Islands, South Africa\# , Spain\# ${ }^{\#}$, Sri Lanka\# , Suriname, Swaziland, Sweden\# ${ }^{\#}$ Switzerland ${ }^{\#}$, Tanzania, Thailand\#, Trinidad \& Tobago, Turkey, Uganda, Ukraine, United Arab Emirates, United Kingdom\#, United States\#, Uruguay, Uzbekistan, Venezuela\#, Vietnam, Zambia, Zimbabwe.

2. Variable name (number of observations; mean; standard deviation; minimum value; maximum value), description and source.

- Capital market openness index (3250; 0.068; 1.548; -1.753; 2.623): Chinn-Ito capital openness measure. This indicator assumes higher values when countries become more open. Chinn and Ito [12]. Dataset downloadable at: www.ssc.wisc.edu. 
- Corporate tax rate $(2209 ; 34.32 ; 10.78 ; 0 ; 75)$ : central government top corporate income statutory tax rate. World Tax Database at the Michigan Ross School of Business (www.bus.umich.edu), integrated with data from World Bank (WDI) and from KPMG (Corporate tax rates survey, issues from 1998 to 2003).

- Education $(2131 ; 3.50 ; 1.71 ; 0.30 ; 7.67)$ : average years of schooling of people aged 25 or more. This variable should capture the human capital endowment of a country. Data are provided on a five years basis. Consequently, in years with missing data -since this variable evolves slowly over time-, we have considered it as constant and equal to the most recent data available. Quality of Governance Dataset (www.qog.pol.gu.se). Original Source: Barro-Lee Education Attainment dataset.

- Employment $(3176 ; 0.444 ; 0.066 ; 0.241 ; 0.599)$ : ratio of total employment over total population. This variable should measure the importance of the tax base composed of wages and salaries. Own calculations based on PWT data.

- FDI inflow $(2689 ; 5.109 ; 3.162 ;-9.557 ; 16.403)$ : log of the total inflow of FDI in constant 2000 USA millions of dollars. UNCTAD, FDI indicators, available at http://stats.unctad.org/fdi/. Converted into constant 2000 USA dollar using local currency/USA dollar nominal exchange rate taken from PWT and CPI from IMF, International Financial Statistics.

- FDI outflow $(1996 ; 3.802 ; 4.265 ;-15.57 ; 17.103)$ : log of the total outflow of FDI expressed inconstant 2000 USA dollars. UNCTAD, FDI indicators, available at http://stats.unctad.org/fdi/. Converted into constant 2000 USA dollar using local currency/USA dollar nominal 
exchange rate taken from PWT and CPI from IMF, International Financial Statistics.

- Infrastructure index $(2260 ;-2.32 ; 1.93 ;-6.62 ; 1.78)$ : ratio of the $\log$ of the length of the road and railway line network over the log of the total country area. This variable should measure the infrastructure endowment of the country. Data are provided on a five years basis. Consequently, in years with missing data -since this variable evolves slowly over time-, we have considered it as constant and equal to the most recent data available (see Serven and Calderon [9]).

- Old $(3591 ; 6.232 ; 4.274 ; 1.00 ; 19.33)$ : share of population aged 65 or more. WDI.

- Young $(3591 ; 34.76 ; 10.27 ; 14.11 ; 50.40)$ : share of population aged 14 or less. WDI.

- Personal income tax $(1974 ; 38.28 ; 18.17 ; 0 ; 90)$ : central government top personal income tax rate. World Tax Database at the Michigan Ross School of Business (www.bus.umich.edu) . Integrated with data from the World Bank (WDI) and, for OECD countries, with data from the OECD Tax Database.

- Public spending $(3447 ; 23.663 ; 10.950 ; 2.12 ; 98.27)$ : government expenditure share of GDP. Penn World Tables (PWT).

- Size $(3447 ; 16.807 ; 2.269 ; 10.806 ; 23.112)$ : log of Purchasing Power Parity Gross Domestic Product in thousands of currency units. Penn World Tables (PWT).

- Urbanization $(3771 ; 51.20 ; 23.70 ; 4.22 ; 100)$ : share of urban population. WDI. 
- Exchange rate volatility $(3393 ; 25.37 ; 73.97 ; 0 ; 798.8)$ : standard deviation in the rate of growth of the nominal exchange rate with the USA dollar. In the estimates that use this variable, the USA was dropped from the sample. PWT.

- GDP volatility $(3313 ; 5.419 ; 5.308 ; 0.258 ; 60.035)$ : standard deviation of the GDP growth rate in the preceding five years. GDP is in Purchasing Power Parity. Penn World Tables (PWT).

- Interest rate volatility $(2308 ; 5.84 ; 9.81 ; 0.17 ; 346.20)$ : standard deviation of the real interest rate (defined as nominal lending rate minus inflation rate computed as the rate of growth of the GDP deflator) in the preceding five years. WDI.

- Political instability $(3801 ; 0.469 ; 0.694 ; 0 ; 4)$ : total number of changes, recorded in the preceding five years, in the executive composition. Own calculations based on data taken from the Polcon dataset (wwwmanagement.wharton.upenn.edu).

- Property rights protection $(2417 ; 5.518 ; 1.885 ; 1.022 ; 9.624)$ : degree of property rights protection. Fraser Institute (www.freetheworld.com). Until 1999, this variable is provided on a five years basis. Consequently, in years with missing data -since this variable evolves slowly over time-, we have considered it as constant and equal to the most recent data available.

\section{Notes:}

1. \#FDI data available.

2. PWT refers to: Alan Heston, Robert Summers and Bettina Aten, Penn World Table Version 6.2, Center for International Comparisons of Production, Income and Prices at the University of Pennsylvania, September 2006 . 
3. WDI: World Development Indicators (2006), World Bank.

4. The FDI inflow and outflow variables comprise capital provided (either directly or through other related enterprises) by a foreign direct investor to a FDI enterprise or capital received by a foreign direct investor from a FDI enterprise. FDI includes the three following components: equity capital, reinvested earnings and intra-company loans. Equity capital is the foreign direct investor's purchase of shares of an enterprise in a country other than that of its residence. Reinvested earnings include the direct investor's share (in proportion to direct equity participation) of earnings not distributed as dividends by affiliates or earnings not remitted to the direct investor. Such retained profits by affiliates are reinvested. Intra-company loans or intra-company debt transactions refer to short- or long-term borrowing and lending of funds between direct investors (parent enterprises) and affiliated enterprises. 


\title{
CESifo Working Paper Series
}

\author{
(for full list see www.cesifo-group.de)
}

1904 Stephane Dees, Sean Holly, M. Hashem Pesaran and L. Vanessa Smith, Long Run Macroeconomic Relations in the Global Economy, January 2007

1905 Richard Jong-A-Pin and Jakob De Haan, Political Regime Change, Economic Reform and Growth Accelerations, January 2007

1906 Sascha O. Becker and Peter H. Egger, Endogenous Product versus Process Innovation and a Firm's Propensity to Export, February 2007

1907 Theo S. Eicher, Chris Papageorgiou and Oliver Roehn, Unraveling the Fortunates of the Fortunate: An Iterative Bayesian Model Averaging (IBMA) Approach, February 2007

1908 Liliana E. Pezzin, Robert A. Pollak and Barbara S. Schone, Efficiency in Family Bargaining: Living Arrangements and Caregiving Decisions of Adult Children and Disabled Elderly Parents, February 2007

1909 Christian Keuschnigg and Soren Bo Nielsen, Self-Selection and Advice in Venture Capital Finance, February 2007

1910 Rune Jansen Hagen and Gaute Torsvik, Irreversible Investments, Dynamic Inconsistency and Policy Convergence, February 2007

1911 Eric A. Hanushek and Ludger Woessmann, The Role of School Improvement in Economic Development, February 2007

1912 Bernard M. S. van Praag, Perspectives from the Happiness Literature and the Role of New Instruments for Policy Analysis, February 2007

1913 Volker Grossmann and Thomas M. Steger, Growth, Development, and Technological Change, February 2007

1914 Margarita Katsimi and Thomas Moutos, Human Capital and the Feldstein-Horioka Puzzle, February 2007

1915 Oliver Roehn, Theo S. Eicher and Thomas Strobel, The Ifo Industry Growth Accounting Database, February 2007

1916 Ian Babetskii, Aggregate Wage Flexibility in Selected New EU Member States, February 2007

1917 Burkhard Heer, Alfred Maussner and Paul D. McNelis, The Money-Age Distribution: Empirical Facts and Limited Monetary Models, February 2007

1918 Yin-Wong Cheung, Menzie D. Chinn and Eijii Fujii, The Overvaluation of Renminbi Undervaluation, February 2007 
1919 Jim Malley, Apostolis Philippopoulos and Ulrich Woitek, To React or Not? Fiscal Policy, Volatility and Welfare in the EU-3, February 2007

1920 Mattias Polborn, Competing for Recognition through Public Good Provision, February 2007

1921 Lars P. Feld and Benno Torgler, Tax Morale after the Reunification of Germany: Results from a Quasi-Natural Experiment, February 2007

1922 Robert S. Chirinko and Huntley Schaller, Fundamentals, Misvaluation, and Investment: The Real Story, February 2007

1923 Benno Torgler and Friedrich Schneider, Shadow Economy, Tax Morale, Governance and Institutional Quality: A Panel Analysis, February 2007

1924 Adrian Pagan and M. Hashem Pesaran, On Econometric Analysis of Structural Systems with Permanent and Transitory Shocks and Exogenous Variables, February 2007

1925 Hans-Werner Sinn, The Welfare State and the Forces of Globalization, February 2007

1926 Michael Smart, Raising Taxes through Equalization, February 2007

1927 Øystein Foros, Kåre P. Hagen and Hans Jarle Kind, Price-Dependent Profit Sharing as an Escape from the Bertrand Paradox, February 2007

1928 Balázs Égert, Kirsten Lommatzsch and Amina Lahrèche-Révil, Real Exchange Rates in Small Open OECD and Transition Economies: Comparing Apples with Oranges?, February 2007

1929 Aleksander Berentsen and Cyril Monnet, Monetary Policy in a Channel System, February 2007

1930 Wolfgang Ochel, The Free Movement of Inactive Citizens in the EU - A Challenge for the European Welfare State?, February 2007

1931 James K. Hammitt and Nicolas Treich, Statistical vs. Identified Lives in Benefit-Cost Analysis, February 2007

1932 Wilhelm Kohler, The Bazaar Effect, Unbundling of Comparative Advantage, and Migration, February 2007

1933 Karsten Staehr, Fiscal Policies and Business Cycles in an Enlarged Euro Area, February 2007

1934 Michele Bernasconi and Paola Profeta, Redistribution or Education? The Political Economy of the Social Race, March 2007

1935 Axel Dreher, Martin Gassebner and Lars-H. R. Siemers, Does Terror Threaten Human Rights? Evidence from Panel Data, March 2007 
1936 Naércio Aquino Menezes Filho and Marc-Andreas Muendler, Labor Reallocation in Response to Trade Reform, March 2007

1937 Gebhard Flaig and Timo Wollmershaeuser, Does the Euro-zone Diverge? A Stress Indicator for Analyzing Trends and Cycles in Real GDP and Inflation, March 2007

1938 Michael Funke and Michael Paetz, Environmental Policy Under Model Uncertainty: A Robust Optimal Control Approach, March 2007

1939 Byeongchan Seong, Sung K. Ahn and Peter A. Zadrozny, Cointegration Analysis with Mixed-Frequency Data, March 2007

1940 Monika Bütler and Michel André Maréchal, Framing Effects in Political Decision Making: Evidence from a Natural Voting Experiment, March 2007

1941 Giacomo Corneo and Olivier Jeanne, A Theory of Tolerance, March 2007

1942 Qing Hong and Michael Smart, In Praise of Tax Havens: International Tax Planning and Foreign Direct Investment, March 2007

1943 Yin-Wong Cheung, Dickson Tam and Matthew S. Yiu, Does the Chinese Interest Rate Follow the US Interest Rate?, March 2007

1944 Panu Poutvaara and Mikael Priks, Unemployment and Gang Crime: Could Prosperity Backfire?, March 2007

1945 Burkhard Heer, On the Modeling of the Income Distribution Business Cycle Dynamics, March 2007

1946 Christoph A. Schaltegger and Lars P. Feld, Are Fiscal Adjustments less Successful in Decentralized Governments?, March 2007

1947 Giovanni Facchini, Marcelo Olarreaga, Peri Silva and Gerald Willmann, Substitutability and Protectionism: Latin America's Trade Policy and Imports from China and India, March 2007

1948 C. Mirjam van Praag and Bernard M. S. van Praag, The Benefits of Being Economics Professor A (and not Z), March 2007

1949 Astrid Hopfensitz and Frans van Winden, Dynamic Choice, Independence and Emotions, March 2007

1950 Guglielmo Maria Caporale and Luis A. Gil-Alana, A Multivariate Long-Memory Model with Structural Breaks, March 2007

1951 Mattias Ganslandt and Keith E. Maskus, Wholesale Price Discrimination and Parallel Imports, March 2007

1952 Michela Redoano, Fiscal Interactions Among European Countries. Does the EU Matter?, March 2007 
1953 Stefan C. Wolter, Rémy Hübschi and Matthias Müller, Push or Pull? An Empirical Analysis of the Demand for Individual Project Grants from the Swiss National Science Foundation, March 2007

1954 Scott Alan Carson, African-American and White Inequality in the American South: Evidence from the $19^{\text {th }}$ Century Missouri State Prison, March 2007

1955 Peter Egger, Marko Koethenbuerger and Michael Smart, Do Fiscal Transfers Alleviate Business Tax Competition? Evidence from Germany, March 2007

1956 Panu Poutvaara and Lars-H. R. Siemers, Smoking and Social Interaction, March 2007

1957 Stephan Danninger and Fred Joutz, What Explains Germany's Rebounding Export Market Share?, March 2007

1958 Stefan Krasa and Mattias Polborn, Majority-efficiency and Competition-efficiency in a Binary Policy Model, March 2007

1959 Thiess Buettner and Georg Wamser, Intercompany Loans and Profit Shifting Evidence from Company-Level Data, March 2007

1960 Per Pettersson-Lidbom and Mikael Priks, Behavior under Social Pressure: Empty Italian Stadiums and Referee Bias, April 2007

1961 Balázs Égert and Carol S. Leonard, Dutch Disease Scare in Kazakhstan: Is it real?, April 2007

1962 Paul De Grauwe and Pablo Rovira Kaltwasser, Modeling Optimism and Pessimism in the Foreign Exchange Market, April 2007

1963 Volker Grossmann and Thomas M. Steger, Anti-Competitive Conduct, In-House R\&D, and Growth, April 2007

1964 Steven Brakman and Charles van Marrewijk, It’s a Big World After All, April 2007

1965 Mauro Ghinamo, Paolo M. Panteghini and Federico Revelli, FDI Determination and Corporate Tax Competition in a Volatile World, April 2007 